\title{
HUBUNGAN SKOR SELEKSI PENERIMAAN MAHASISWA BARU DAN MOTIVASI BELAJAR DENGAN PRESTASI BELAJAR UJIAN TAHAP II
}

\author{
${ }^{1}$ Eko Sari Ajiningtyas \\ ${ }^{1}$ STIKes Borneo Cendekia Medika \\ ${ }^{1}$ Email: mahardikagunardi@gmail.com
}

\begin{abstract}
ABSTRAK
Pendidikan Tenaga Kesehatan (Diknakes) bertujuan menghasilkan tenaga kesehatan yang profesional yang memiliki kemampuan untuk bekerja secara mandiri, mampu mengembangkan diri dan beretika. Berdasarkan pengamatan kasar dari hasil ujian akhir semester dari masing-masing semester yang mendapat rangking 3 besar bukan yang mendapat rangking tinggi dalam seleksi sipenmaru, begitu pula sebaliknya saat sipenmaru mendapatkan rangking rendah belum tentu prestasi belajar juga rendah. Penelitian ini dilakukan untuk mengetahui Hubungan Skor Seleksi Penerimaan Mahasiswa Baru dan Motivasi Belajar dengan Prestasi Belajar Ujian Tahap II. Jenis penelitian ini deskriptif korelasional dengan desain penelitian cross seksional Populasi dalam penelitian ini adalah seluruh mahasiswa semester V tahun akademik 2015/2016, sebanyak 39 mahasiswa. Teknik pengambilan sampel dalam penelitian adalah total sampling. Instrumen yang digunakan adalah data dari BAAK dan kuesioner. Data dianalisis menggunakan analisis korelasi dan regresi ganda. Hasil penelitian ini diketahui hampir separuh dari responden mempunyai skor sipenmaru yang tinggi, yaitu sebanyak 43,6\%, sebagian besar dari responden mempunyai motivasi belajar yang tinggi, yaitu sebanyak 71,8 \% dan hampir seluruh responden mempunyai tingkat prestasi belajar ujian tahap II baik, yaitu sebanyak 97,4\%. kontribusi secara bersama antara variabel bebas terhadap variabel terikat sebesar 48,6\%. Hasil penelitian dapat disimpulkan secara bersama-sama skor sipenmaru dan motivasi belajar memiliki hubungan yang signifikan terhadap prestasi belajar ujian tahap II.
\end{abstract}

Kata Kunci : Skor seleksi penerimaan mahasiswa baru, motivasi belajar, prestasi belajar ujian tahap II

\section{RELATIONSHIP OF SCORE FOR RECEIVING SELECTION OF NEW STUDENTS AND LEARNING MOTIVATION WITH LEARNING ACHIEVEMENT TEST PHASE II}

\section{ABSTRACT}

Health Workforce Education (Diknakes) aims to produce professional health workers who have the ability to work independently, able to develop themselves and be ethical. Based on rough observations from the results of the end of the semester exams from each semester that got the top 3 ranking not the one who got the highest ranking in the selection of sipenmaru, and vice versa when sipenmaru gets a low ranking not necessarily low learning achievement. This study was conducted to determine the relationship of the New Student Admission Selection Score and Learning Motivation 
with the Phase II Exam Learning Achievement. This type of research is descriptive correlational with cross-sectional research design The population in this study were all semester $V$ students of the academic year 2015/2016, as many as 39 students. The sampling technique in this research is total sampling. The instrument used was data from BAAK and questionnaires. Data were analyzed using correlation analysis and multiple regression. The results of this study are known to almost half of the respondents have a high sipenmaru score, which is as much as 43.6\%, most of the respondents have high motivation to learn, which is as much as $71.8 \%$ and almost all respondents have a good level of learning achievement of the second phase of the exam, which is $97.4 \%$. joint contribution between the independent variables to the dependent variable by 48.6\%. The results of the study can be concluded jointly sipenmaru scores and learning motivation have a significant relationship to the achievement of the phase II exam learning.

Keywords: New student admission selection scores, learning motivation, stage II exam learningachievement

\section{PENDAHULUAN}

Pendidikan Tenaga Kesehatan (Diknakes) bertujuan menghasilkan tenaga kesehatan yang profesional yang memiliki kemampuan untuk bekerja secara mandiri, mampu mengembangkan diri dan beretika. Tuntutan masyarakat akan mutu pelayanan kesehatan semakin meningkat seiring dengan peningkatan pengetahuan dan kemampuan masyarakat maupun perkembangan ilmu pengetahuan dan teknologi di bidang kesehatan. Perubahan dan perkembangan tersebut merupakan tantangan untuk meningkatkan kualitas sumber daya manusia kesehatan. Hal ini sangat bergantung dari proses pengadaan tenaga kesehatan melalui penyelenggaraan pendidikan tenaga kesehatan. Penyelenggaraan Sipenmaru Diknakes sesuai dengan pedoman Penyelenggaraan Sipenmaru Diknakes yang ditetapkan melalui surat Keputusan Kementerian Kesehatan Badan Pengembangan dan Pemberdayaan Sumberdaya Manusia
Kesehatan, Nomor HK.00.06/I/III/1/02000/2011, tentang Petunjuk Teknis Penyelenggaraan Seleksi Penerimaan Mahasiswa Baru Pendidikan Tenaga Kesehatan Institusi Pemerintah propinsi/Kabupaten/Kota, TNI, PolRI dan Swasta tahun akademik 2011/2012. (Pusdiknakes RI, 2011).

Berdasarkan pengamatan kasar dari hasil ujian akhir semester dari masing-masing semester yang mendapat rangking 3 besar bukan yang mendapat rangking tinggi dalam seleksi sipenmaru, begitu pula sebaliknya saat sipenmaru mendapatkan rangking rendah belum tentu prestasi belajar juga rendah.

Prestasi belajar mahasiswa dapat dijadikan pedoman penilaian terhadap keberhasilan dalam kegiatan belajar. Prestasi belajar merupakan informasi yang berfungsi untuk mengukur tingkat kemampuan atau keberhasilan belajar mahasiswa, baik perubahan yang bersifat positif maupun negatif. Menurut Purwanto, yang dikutip Waluyo S.J, (2013), hal tersebut 
dapat terjadi karena banyak faktor yang mempengaruhi prestasi belajar diantaranya dukungan keluarga, motivasi, dan minat belajar.

Menurut Sardiman, yang dikutip Waluyo, S.J, (2013), motivasi merupakan salah satu faktor psikologis yang dapat mempengaruhi prestasi belajar mahasiswa yang mengandung unsur bersifat dinamis dalam belajar, seperti perasaan, perhatian, kemauan, dan lain-lain. Motivasi juga dapat dikatakan serangkaian usaha untuk menyediakan kondisi tertentu, sehingga seseorang mau dan ingin melakukan sesuatu, dan bila dia tidak suka, maka akan berusaha untuk meniadakan atau mengelakkan perasaan tidak suka tersebut. Dalam kegiatan belajar, motivasi dikatakan sebagai daya penggerak di dalam diri mahasiswa yang menimbulkan kegiatan belajar.

Dalam penelitian ini mempunyai tujuan, yaitu ; Untuk mengetahui Adakah hubungan antara Skor Seleksi Penerimaan Mahasiswa Baru (Sipenmaru) dengan prestasi belajar ujian tahap II, untuk mengetahui adakah hubungan antara motivasi belajar dengan prestasi belajar ujian tahap II, dan untuk mengetahui adakah hubungan antara skor seleksi penerimaan mahasiswa baru (sipenmaru) dan motivasi belajar dengan prestasi belajar ujian tahap II.

Sipenmaru adalah pelaksanaan seleksi penerimaan mahasiswa baru yang dilakukan berdasarkan aturan yang ditetapkan oleh Kepala Badan Pengembangan Pemberdayaan Sumber Daya Manusia Tenaga Kesehatan dalam bentuk petunjuk teknis pelaksanaan sipenmaru tahun akademik 2015/2016. (Pusdiknakes RI, 2011) Dalam pelaksanaan Sipenmaru teknik penilaian menggunakan dua jenis penilaian yaitu Penilaian Acuan Normatif (PAN) dan Penilaian Acuan Patokan (PAP) dan mata ajar yang diujikan terdiri dari matematika, sebanyak 30 butir soal, bahasa inggris 30 butir soal, IPA (biologi, fisika, kimia) 30 butir soal dan bahasa indonesia 10 butir soal . Bentuk soal adalah obyetif, waktu pelaksanaan selama 180 menit. Scor penilaian di lembar jawaban adalah jika jawaban benar nilainya satu (1), jika salah nilai nol (0). (Pusdiknakes, 2011) Motivasi sebagai suatu perubahan energi dalam diri seseorang yang ditandai dengan munculnya perasaan dan didahului dengan adanya tujuan. menurut Sardiman, 1990:74, dalam motivasi terkandung tiga unsur penting, yaitu : 1). Bahwa motivasi itu mengawali terjadinya perubahan energi pada diri setiap individu manusia, perkembangan motivasi akan membawa beberapa perubahan energi di dalam system "neurophysiological" yang ada pada organisme manusia. 2). Motivasi ditandai dengan munculnya rasa "feeling", afeksi seseorang. Dalam hal ini motivasi relevan dengan persoalanpersoalan kejiwaan, afeksi dan emosi yang dapat menentukan tingkah laku manusia. 3). Motivasi akan dirangsang karena adanya tujuan. Jadi motivasi dalam hal ini sebenarnya merupakan respons dari suatu aksi yakni tujuan.

Adapun pengertian prestasi belajar dalam Kamus Besar Bahasa Indonesia adalah "penguasaan pengetahuan atau keterampilan yang dikembangkan oleh mata pelajaran, lazimnya ditunjukkan dengan nilai tes atau angka nilai yang diberikan oleh guru. Prestasi belajar sebagai indikasi sejauh mana siswa telah menguasai materi pelajaran yang 
disampaikannya, biasanya prestasi belajar ini dinyatakan dengan angka, huruf, atau kalimat dan terdapat dalam periode tertentu. Menurut Slameto (2010), Faktor-faktor yang mempengaruhi prestasi belajar dibagi menjadi dua, yaitu faktor internal dan faktor eksternal. Dengan hipotesis : 1.Ada hubungan antara scor seleksi penerimaan mahasiswa baru dengan prestasi belajar ujian tahap II. 2. Ada hubungan antara motivasi belajar dengan prestasi belajar ujian tahap II. 3 . Ada hubungan scor seleksi penerimaan mahasiswa baru dan motivasi belajar dengan prestasi belajar Ujian tahap II.

\section{METODE PENELITIAN}

Penelitian ini dilaksanakan pada tanggal 15 Februari - 16 April 2016. Jenis penelitian ini deskriptif korelasional dengan desain penelitian cross seksional.

Populasi dalam penelitian ini adalah seluruh mahasiswa semester V tahun akademik 2015/2016, sebanyak 39 mahasiswa, dengan tehnik total sampling.

Data yang digunakan dalam penelitian ini terdiri dari data primer dan data sekunder. Dalam data sekunder ini adalah skor Sipenmaru dari Dinas Kesehatan, yang merupakan hasil nominasi seleksi masuk dan dokumentasi evaluasi Ujian Tahap II dari BAAK. Sedangkan data primer adalah data motivasi belajar yang diperoleh dari kuesioner yang dibagikan langsung kepada responden. Untuk mengetahui hubungan variabel independen dengan dependen, dianalisa dengan analisis korelasi Product Moment, karena data kedua variabel interval. Dan untuk menguji hubungan ketiganya menggunakan analisis dengan regresi linier ganda, karena variabel independen yang berjumlah lebih dari satu.

\section{HASIL DAN PEMBAHASAN}

Hasil dari penelitian diperoleh data karena populasi terbatas maka kuisioner diuji dengan uji validitas terpakai. Dan dari 40 soal yang valid hanya 32 soal. Dengan dibuangnya nomor tersebut validitas isinya masih terpenuhi setelah dicocokkan dengan kisi-kisi. Hampir separuh dari responden mempunyai skor sipenmaru yang tinggi, yaitu sebanyak $43,6 \%$. Sebagian besar dari responden mempunyai motivasi belajar yang tinggi, yaitu sebanyak 71,8 \%. Dan hampir seluruh responden mempunyai tingkat prestasi belajar ujian tahap II baik, yaitu sebanyak 97,4\%.

Uji korelasi antara variabel independen dengan variabel dependen, dengan menggunakan korelasi sederhana Product Moment, dengan bantuan program SPSS 16.0 for windows. Hasilnya sebagai berikut ; hasil analisis didapatkan hubungan antara skor sipenmaru dengan prestasi belajar adalah 0,240, dengan nilai signifikansi dua sisi sebesar 0,142, karena $0,142>0.05$, maka tidak signifikan artinya Ho ditolak dan $\mathrm{Ha}$ diterima. Dan hubungan antara motivasi belajar dengan prestasi belajar adalah 0,935 , dengan nilai signifikansi dua sisi sebesar 0,000, karena 0,000 < 0,05 maka signifikan, artinya Ho ditolak dan Ha diterima.

Analisis Korelasi Product Moment (Pearson Correlation). Hasil dari analisis antara variabel bebas skor sipenmaru (X1), motivasi belajar (X2) dengan variabel terikat yaitu prestasi 
belajar (Y) didapatkan hasil R (koefisien korelasi) 0,697, hal ini menunjukkan hubungan kuat. Artinya ada hubungan positif yang kuat antara variabel bebas dengan variabel terikat.

Hasil Uji Regresi Linier Ganda, perubahan nilai rerata $\mathrm{X}_{2}$ terhadap $\mathrm{Y}$ adalah 0,190. hasil keputusan regresi ganda pada variabel bebas terhadap variabel terikat yaitu diperoleh nilai $F_{\text {hitung }}=17,019$, Ftabel $=3,26$, dan nilai signifikan 0,000. Karena Fhitung > Ftabel dan nilai signifikan $<0.05$, maka model regresi dapat digunakan untuk prediksi, artinya secara bersama-sama variabel bebas berpengaruh terhadap variabel terikat.

Pembahasan dalam penelitian ini adalah hasil uji analisis Spearmans tidak memberikan hubungan yang signifikan antara skor seleksi penerimaan mahasiswa baru dengan prestasi belajar ujian tahap II. Hasil skor seleksi penerimaan mahasiswa baru yang dihitung menggunakan penilaian acuan normatif dan mata pelajaran yang diujikan adalah matematika, bahasa Inggris, IPA, bahasa Indonesia tidak memberikan hubungan dengan prestasi belajar ujian tahap II artinya prestasi belajar ujian tahap II mahasiswa yang tinggi belum tentu saat seleksi penerimaan mahasiswa baru nilainya juga tinggi, dan mahasiswa yang nilai seleksi penerimaan mahasiswa rendah belum tentu memiliki prestasi rendah, hal ini kemungkinan ada faktor-faktor lain yang mempengaruhi prestasi belajar ujian tahap II mahasiswa. Faktor terbebut seperti latar belakang pendidikan mahasiswa, dan metode ujian yang berbeda. Menurut Nurkancana dan Sunartana yang dikutip Suswarti (2009) mengatakan prestasi belajar disebut kecakapan aktual (actual ability) yang diperoleh seseorang setelah belajar, suatu kecakapan potensial (potensial ability) yaitu kemampuan dasar yang berupa disposisi yang dimiliki oleh individu untuk mencapai prestasi. Kecakapan aktual dan kecakapan potensial ini dapat dimasukkan kedalam suatu istilah yang lebih umum yaitu kemampuan (ability).

Mengingat,tes mata pelajaran matematika, bahasa Inggris, IPA, dan bahasa Indonesia yang dipergunakan untuk menentukan penerimaan mahasiswa tidak mempunyai hubungan dengan prestasi belajar ujian tahap II, maka perlu dievaluasi desain seleksi penerimaan mahasiswa tersebut. Seleksi penerimaan mahasiswa baru yang telah berlangsung selama ini masih tetap dapat dipergunakan sebagai dasar untuk menentukan batas kelulusan (passing grade) yang optimal, dan perlu dikembangkan seleksi yang lain seperti Tes Intelegenci (tes IQ) untuk mengetahui kemampuan umum individu dalam menyesuaikan diri dengan lingkungannya. Tes Bakat untuk mengetahui keahlian dan ketrampilan dalam suatu bidang pekerjaan yaitu sebagai seorang bidan. Tes Ketahanan Emosi dapat dipergunakan untuk mengidentifikasi, mengukur ketahanan emosi sehingga saat memasuki kehidupan yang lain atau dunia profesi mampu mengelola emosi dengan lebih baik.

Hasil analisis didapatkan ada hubungan signifikan antara motivasi belajar dengan prestasi belajar .Sumbangan efektif motifasi belajar terhadap prestasi belajar sebesar $48,6 \%$, dan sumbangan relatif $100 \%$. Hal tersebut mempunyai arti bahwa motivasi belajar mempunyai pengaruh yang dominan terhadap prestasi belajar ujian 
tahap II. Motivasi merupakan dorongan yang terdapat dalam diri seseorang untuk berusaha mengadakan perubahan tingkah laku yang lebih baik dalam memenuhi kebutuhannya. (Uno, 2011:3). Motivasi belajar tidak selamanya stabil. Hal ini disebabkan banyak beberapa faktor yang mempengaruhi motifasi belajar tersebut seperti; kemampuan, kondisi lingkungan, dan lain-lain. Faktor tersebut harus diketahui dosen, guna memperkuat dan memelihara faktor yang dapat meningkatkan motivasi dan menghindari faktor yang melemahkan motivasi. Dengan semangat yang tinggi maka pencapaian prestasi belajar akan semakin mudah.

Dari hasil penelitian bahwa motivasi sangat erat hubungannya dengan prestasi belajar. Dalam hal ini jika mahasiswa ingin memperoleh hasil yang tinggi maka harus mempunyai motivasi belajar yang keras. Mahasiswapun juga harus punya tujuan untuk dijadikan motivasi belajarnya yaitu menjadi bidan yang profesional. Dengan motivasi tersebut maka akan memacu mahasiswa untuk melakukan hal-hal yang mendukung untuk mencapai tujuan.

Hasil penelitian ini sesuai dengan hipotesis yaitu ada hubungan signifikan antara skor seleksi penerimaan mahasiswa baru dan motivasi belajar dengan prestasi belajar ujian tahap II. Skor seleksi penerimaan mahasiswa baru dan motivasi belajar dengan prestasi belajar ujian tahap II memberikan kontribusi sebesar 48,6\%. Dan variabel yang lebih dominan dalam mempengaruhi prestasi belajar ujian tahap II adalah motivasi belajar.

Dengan dinyatakan lulus ujian sipenmaru maka mahasiswa tersebut telah memenuhi standar yang diharapkan. Sehingga setelah memasuki AkBid melalui proses belajar mengajar akan pula diperoleh prestasi belajar yang baik dan pada akhirya dapat dihasilkan lulusan ahli madya kebidanan yang mutunya dapat dipertanggungjawabkan.

Prestasi belajar merupakan suatu kemajuan dalam perkembangan siswa setelah ia mengikuti kegiatan belajar dalam waktu tertentu. Seluruh pengetahuan, ketrampilan, kecakapan dan perilaku individu terbentuk dan berkembang melalui proses belajar. Menurut Slameto (2010), bahwa prestasi belajar salah satunya dipengaruhi oleh motivasi. Motivasi erat hubungannya dengan tujuan yang akan dicapai dalam belajar, di dalam menentukan tujuan itu dapat disadari atau tidak, akan tetapi untuk mencapai tujuan itu perlu berbuat, sedangkan yang menjadi penyebab berbuat adalah motivasi itu sendiri sebagai daya penggerak atau pendorongnya.

Dari hasil penelitian ini sesuai dengan teori tersebut, dalam hipotesa yang pertama bahwa skor sipenmaru tidak ada hubungan signifikan dengan prestasi belajar ujian tahap II, tetapi dalam proses belajar didukung motivasi belajar mahasiswa yang tinggi maka mahasiswa mampu mencetak prestasi belajar ujian tahap II yang baik.

\section{KESIMPULAN DAN SARAN}

Hasil penelitian ini dapat disimpulkan sebagai berikut ; 1. tidak ada hubungan yang signifikan antara Skor sipenmaru dengan Prestasi belajar Ujian Tahap II, 2. motivasi belajar mempunyai hubungan yang signifikan dengan prestasi belajar Ujian Tahap II, 
3. Secara bersama-sama skor sipenmaru dan motivasi belajar memiliki hubungan yang signifikan terhadap prestasi belajar ujian tahap II, dengan kontribusi secara bersama-sama dari variable bebas dengan variable terikat sebesar 48,6\% dan sisanya dari factor yang lain. Sumbangan efektif semua berasal dari motivasi belajar. Saran diberikan kepada ; 1. Institusi Pendidikan dalam seleksi penerimaan mahasiswa baru, dievaluasi ulang dalam materi tes, bisa dirubah dengan tes psikologi berhubungan dengan minat/motivasi sehingga dapat menjadi gambaran terhadap kemampuan mahasiswa sehingga dapat merencanakan proses pembelajaran yang efektif, 2. Bagi dosen yang edukatif di institusi pendidikan hendaknya memahami karakteristik mahasiswa dan selalu memberikan motivator agar mahasiswa dapat belajar baik formal maupun non formal, dan 3. Mahasiswa Selalu berusaha meningkatkan motivasi yang bisa mengungkit belajarnya agar tujuan bisa tercapai maksimal.

\section{DAFTAR PUSTAKA}

Departemen Pendidikan dan Kebudayaan. 1999. Kamus Besar Bahasa Indonesia. Jakarta: Balai Pustaka. Cetakan 10 : hal 787.

FKPKK. 2005. Pedoman Penyelenggaraan Ujian Tahap I, II, dan III. Surabaya. Jawa Timur

Ghozali I. 2008. Aplikasi Analisis Multivariat dengan Program SPSS. Semarang : Badan Penerbit Universitas Diponegoro
KeMenKes RI, Badan PPSDM Kesehatan, Pusdiknakes. 2010. Standar Penilaian Pendidikan Tenaga Kesehatan. Jakarta

Kep.Men.Kes.R.I, No. HK 00.06.2.4.1583, 2002 Tentang Kurikulum Pendidikan Diploma III Kebidanan. Jakarta

Pusdiknakes. 2011. Petunjuk Teknis Penyelenggaraan Seleksi Penerimaan Mahasiswa Baru Pendidikan Tenaga Kesehatan Tahun Akademik 2011/2012. Jakarta

Sardiman A.M. 1990. Interaksi dan Motivasi Belajar Mengajar. Jakarta : CV Rajawali

Slameto. 2003. Belajar dan Faktorfaktor yang Mempengaruhinya. Jakarta : Rineka Cipta.

Slameto. 2010. Belajar dan Faktorfaktor yang Mempengaruhinya. Jakarta : Rineka Cipta.

Suswarti, I, 2009, Korelasi antara Nilai Seleksi

Penerimaan Mahasiswa Baru dan Prestasi Akademik Mahasiswa Fakultas

Uno,Hamzah B. 2011. Teori Motivasi dan Pengukurannya. Jakarta : PT Bumi Aksara

Waluyo, S.J, 2013. Hubungan Antara Hasil Seleksi Mahasiswa Baru (Sipenmaru), Minat dan Motivasi Belajar dengan Prestasi Belajar Mahasiswa dalam Mata Kuliah Sistem Integumen di Akademi Keperawatan PPNI Surakarta 